\title{
SWOT-PEST Analysis and Research on the Development of Chinese Table Tennis in the New Era
}

\author{
JingyiXie, LiZhang*,ZhenyingZhang \\ Department of Physical Education, China University of Mining and Technology, Beijing 100083, P.R. \\ China \\ * Corresponding author
}

\begin{abstract}
Sports is playing an increasingly important role in China's education construction. Recently, President emphasized the need to accelerate the construction of a sports power in important meetings. The development of sports is closely related to people's living standards. It can not only expand people's physical exercise channels, but also further enrich people's leisure life. At the same time, President pointed out that sports activities are an important driving force for economic development in the new era and an important representative of the country's soft power. In this context, the author will study the development of table tennis in China in the new era on the basis of combing the literature, combined with SWOT-PEST and other research methods. Research on the development status and motivation of table tennis. Its research shows that with the advancement of science and technology in recent years, the optimization of the external environment will promote the positive trend of table tennis sports, adding a force to the development of national sports and great health.
\end{abstract}

Keywords: Table tennis,SWOT-PEST,sports

\section{Introduction}

In this study, the SWOT-PEST analysis model was used to conduct research from different perspectives. The SWOT analysis method[1] and PEST analysis method [2] are commonly used tools for strategic management of the sports industry, which are applicable to all management dimensions and aspects. The SWOT analysis method is an overall situation analysis based on the internal conditions and external environment of the enterprise[3]. In short, using this analysis method can enable better understanding of the pros and cons of the research object.A matrix list is used to scientifically combine the actual influencing factors, so that a scientific solution can be proposed. Based on the matrix analysis results, the author analyzes the strength and weakness, opportunities, threats inChinese table tennis development from the four dimensions of economy, politics, society and technology[4]. The specific model frame structure is shown in Table1 and Table 2.

Table 1SWOT analysis model

\begin{tabular}{|c|c|c|c|c|}
\hline Category & Politics & Economy & Society & Technology \\
\hline Strength & Political Strength & Economic Strength & Social Strength & TechnologicalStrength \\
Weakness & Political Weakness & EconomicWeakness & Social Weakness & TechnologicalWeakness \\
\hline Opportunity & Political Opportunity & Economic Strength & SocialOpportunity & TechnologicalOpportunity \\
\hline Threat & Political Threat & Economic Weakness & Social Threat & Technological Threat \\
\hline
\end{tabular}

Table 2 SWOT-PEST matrix

\begin{tabular}{|c|c|}
\hline Strength & Opportunity \\
\hline Weakness & Threat \\
\hline
\end{tabular}

ISSN: 0010-8189

(C) CONVERTER 2021

Www.converter-magazine.info 


\section{Analysis on the Strengths, Weaknesses, Opportunities and Threats of Table Tennis Development in ChinaBased on the PEST Model}

\subsection{Strength}

\subsubsection{Historical factors}

Table tennis, as China's national sport, has a broad mass base across the country. Before the founding of the People's Republic of China, only a few China's athletes participated in the Olympics, not to mention winning Olympic medals. Soon after the founding of New China, in order to improve the health of the whole people, the former national leader once called on us to "developsports and enhance the people's physique" [5]. As a result, table tennis quickly developed and spread throughout the country, presenting a thriving and prosperous scene. In the next few years, Rong Guotuan, China's first table tennis player winning the world championship, laid a solid foundation for the long-term development of Chinese table tennis. For table tennis, there are no strict standards for participants in all aspects, so the national participation in the sport is greatly increased. At the same time, the United States adopted isolation and blockade foreign policy towards China, but the development and interaction of table tennis loosened the relationship between the two countries. In 1971, the 31st World Table Tennis Championship was successfully held. By participating in this competition, China further established friendly relations with other countries, especially actively promoting the development of friendly diplomatic relations between China and the United States. Since then, "ping-pong diplomacy" of turning the big ball viaa small ballopened up a new situation for the diplomatic relations between China and the United States[6].

\subsubsection{Beneficial to the all-round development of body and mind}

Numerous studies believe that long-term practice of table tennis can promote the human body coordination, enhance nervous system flexibility, improve response ability, prevent myopia and even improve vision. Table tennis developsquite fast, and its flying speed can reach 20 meters per second. In ordinary table tennis, the instant reaction speed of the participants is required to reach a very fast standard. The eye lens of the sports participants will also be greatly exercised, and one will not be able to continue this exercise in case of slight inattention[7]. In elementary school, more and more parents let their children participate in this sport, which is because table tennis can prevent myopiato a large extent. At the same time, some researchers have concluded through a twelve-week table tennis exercise experiment that long-term adherence to table tennis can improve the dynamic balance of the elderly, and prevent the elderly from fallingto a certain extent [8]. Therefore, long-term adherence to table tennis can be used as a sport to improve the balance of the elderly. Some researchers also believe that continuous lowand medium-intensity table tennis training can maintain the body's $\mathrm{T}$ cell immune function at a high level through continuous and regular stimulation of the body's nerve-endocrine-immune system, thus enhancing the body's resistance [9]. From another point of view, table tennis requires at least two people to make a round hit, which can enhance communication between people, provide a good platform for establishing interpersonal relationships, and promote individual's physical and psychological development in an all-round way. In summary, table tennis is a sport suitable for all ages.

\subsubsection{Good development momentum of the sports industry}

According to the latest data from the National Bureau of Statistics, in 2020, China began to strengthen investigations into the construction of sports venues and other infrastructure. At the same time, China's sports industry had a development scale of about 2657.9 billion yuan in $2018^{[10]}$, an increase of 1007.8 billion yuan compared to 2017, and the sports industry accounted for $1.1 \%$ of the gross national product. In 2019 , sports venues in China totaled 3.162 million, with a per capita sports area of 1.86 square meters. There were a total of 2,001,400 ball sports venues across the country, with 861,000 table tennis and badminton courts, accounting for $43.02 \%$. It is not difficult to see that table tennis and badminton courts account for nearly half of all ball courts, which sufficiently demonstrates that table tennis enjoys considerable protectionfrom China's sports investment in venues and hardware facilities, thus providing ample ground protection for table tennis participation by the whole people.

\subsection{Weakness}

ISSN: 0010-8189

(C) CONVERTER 2021 
In the late 1850s, Rong Guotuan won the world men's singles championship as China's first world champion. Since then, Chinese table tennis team has gradually seized the top position of this event and even taken the overlord position. However, due to the advanced technique of Chinese table tennis team, the game features fast speed, rough lines, and strong serve rotation. There are often a few rounds in the game, which is prone to lack of ornamental value in the game. Without ornamental value in the game, it is naturally impossible to expand the audience base. The ITTF also constantly changes the rules to increase the rounds of table tennis competitions so that the game is more enjoyable, such as changing from 21-point system to 11-point system, from covered serve to uncovered serve, from celluloid material ball to new material plastic ball[11]. Undoubtedly, changes in these rules will continuouslyincrease the difficulty for the Chinese table tennis team to play in the arena, but these did not affect the final results of Chinese table tennis team in major world events. In the two most recent Olympic Games, the male and female teams of Chinese table tennis representative teams have won all the gold medals in team events and the champions and runners-up in singles events. Therefore, in the hearts of the Chinese people, there will be a mentality that "as long as Chinese table tennis team participates in the competition, it will definitely be the champion". In competitive sports, if the audience think there is no suspense in the game, it will be difficult to attract people to concern about and watch the game. In more cases, it ismerely to see the final result.

\subsection{Opportunity}

\subsubsection{Policy support}

Sports level is an important part of the country's comprehensive national strength. Only with the support of relevant national policies can the sport receive more support and development, so that it develops towards higher goal and better direction. At the forum of sports expertrepresentatives in 2020, the President pointed out[12] that China has entered the "14th Five-Year Plan" period, during which time it is necessary to focus on the actual needs of the people in planning and development. For example, consideringpeople's ever-increasing demand for business culture, the state must propose corresponding development policies and make scientific plans. In terms of sports construction, there is need to further improve infrastructure construction, guarantee the per capita share of sports venues, and ensure people's sports space. In this way, it is possible to better promote the construction and development of national sports, provide people with better venues for sports activities, and improve the national sports quality.

At the same time, the Premier of the State Council also mentioned at the 2020 State Council executive meeting that the sudden epidemic has made us fully aware of the close relationship between physical exercise and quality of the nation[13].Scientific physical exercise can effectively guarantee the basic physical fitness of the people and improve the ability to resist diseases. At the same time, the Prime Minister proposed suggestions of further increasing the construction and planning of basic products such as sports facilities to meet people's physical exercise needs. Moreover,there is need to increase the market supply of high-quality sports products to meet people's sports needs. It can be seen that the country attaches great importance to sports. The state continuously build sports infrastructure in communities, parks, etc., to provide people with more convenient sports venues, and guarantee people's schedule of sports activities.

Regarding table tennis, it is a relatively important sports event in China. Therefore, Chinese Table Tennis Association has also issued corresponding promotion policies to advance the table tennis development in China. For any sport, talent is an important factor driving its development, which is also an important foundation for guaranteeingits lasting development. In terms of table tennis, Chinese Table Tennis Association attaches great importance to the cultivation of talents, selects reserve talents with better foundation and higher qualityfor the table tennis development to lay a solid foundation in this regard. Seen from the current domestic development in sports, Chinese Table Tennis Association has held many meetings on selecting professional and experienced coaches to manage and cultivate reserve talents. For example, the association has repeatedly selected talents from various channels such as society, sports teams, schools and clubs in order to promote the sustainable development of table tennis in China. With the continuous progressin people's awareness of sports, more importance is attached to sports,

ISSN: 0010-8189

(C) CONVERTER 2021 
which can better advance the development of youth sports and cultivate more excellent reserve talents for table tennis (see Table 3).

Table 3 Statistics of Development Policy for China's Sports Industry

\begin{tabular}{|c|c|c|c|}
\hline $\begin{array}{l}\text { Release } \\
\text { time }\end{array}$ & $\begin{array}{c}\text { Release } \\
\text { organization }\end{array}$ & $\begin{array}{l}\text { Policy notice or news } \\
\text { report }\end{array}$ & Specific content \\
\hline May 2016 & $\begin{array}{l}\text { the General } \\
\text { Office of the } \\
\text { State Council }\end{array}$ & $\begin{array}{l}\text { "Opinions on } \\
\text { Strengthening Physical } \\
\text { Education in Schools to } \\
\text { Promote Students' } \\
\text { All-round Development in } \\
\text { Physical and Mental } \\
\text { Health" [14] }\end{array}$ & $\begin{array}{l}\text { It clearly stipulates that all primary and secondary } \\
\text { schools across the country should guarantee students' } \\
\text { physical education time. It is forbidden to compress } \\
\text { or squeeze physical education lessons in various } \\
\text { ways, so that every student receives physical exercise } \\
\text { at school for no less than } 1 \text { hour every day.It is } \\
\text { necessary toinstruct social organizations and families } \\
\text { to create a good sports environment for students, } \\
\text { providegood exercise conditions, and improve the } \\
\text { physical fitness of college, middle, and elementary } \\
\text { school students. }\end{array}$ \\
\hline $\begin{array}{c}\text { November } \\
2019\end{array}$ & $\begin{array}{c}\text { China Sports } \\
\text { News }\end{array}$ & $\begin{array}{l}\text { Puyang, Henan: Polish the } \\
\text { city's vitality card, table } \\
\text { tennis [15] }\end{array}$ & $\begin{array}{l}\text { Speaking of table tennis, we must mention Henan } \\
\text { Puyang. In this city, people of all ages from } \\
\text { 80-year-olds to elementary school students are } \\
\text { actively participating in table tennis. For example, the } \\
\text { 80-year-old coach Zheng Fangde trains table tennis } \\
\text { enthusiasts in various industries. They use their } \\
\text { passion for table tennis to contribute to the sports of } \\
\text { this city and promote the development of table tennis } \\
\text { city. }\end{array}$ \\
\hline April 2020 & $\begin{array}{c}\text { China Sports } \\
\text { News }\end{array}$ & $\begin{array}{c}\text { Fun table tennis } \\
\text { contributes to home fitness } \\
{[16]}\end{array}$ & $\begin{array}{c}\text { Due to the epidemic, more and more friends are } \\
\text { devoting themselves to family table tennis exercises } \\
\text { by making full use of the existing conditions at home } \\
\text { and even finding more tricks, thus achieving the } \\
\text { effect of enhancing physical fitness and relaxing the } \\
\text { mood. }\end{array}$ \\
\hline $\begin{array}{l}\text { August } \\
2020\end{array}$ & $\begin{array}{l}\text { Chinese Table } \\
\text { Tennis } \\
\text { Association }\end{array}$ & $\begin{array}{c}\text { "Announcement on the } \\
\text { Establishment of the } \\
\text { National Table Tennis } \\
\text { Youth Training Team and } \\
\text { Children's Training Team" } \\
\text { [17] }\end{array}$ & $\begin{array}{l}\text { For Chinese Table Tennis Association, the core } \\
\text { purpose is to promote the sustainable development of } \\
\text { table tennis, cultivate more high-quality reserve } \\
\text { talents for the sportsso that more people participate in } \\
\text { table tennis. }\end{array}$ \\
\hline $\begin{array}{c}\text { September } \\
2020\end{array}$ & $\begin{array}{c}\text { China Sports } \\
\text { News }\end{array}$ & $\begin{array}{l}\text { Sichuan staged table tennis } \\
\text { competitions on the field } \\
{[18]}\end{array}$ & $\begin{array}{c}\text { For example, the "Hundreds of Cities and Thousands } \\
\text { of Villages"competition hosted by the Sichuan Table } \\
\text { Tennis Association can better expand the table tennis } \\
\text { masses, attract more people to this sport. Through } \\
\text { sports participation, it is possible to improve people's } \\
\text { physical fitness and further enrich people's amateur } \\
\text { cultural life. }\end{array}$ \\
\hline $\begin{array}{c}\text { November } \\
2020\end{array}$ & $\begin{array}{l}\text { Chinese Table } \\
\text { Tennis } \\
\text { Association }\end{array}$ & $\begin{array}{c}\text { Supplementary Notice on } \\
\text { the } 2020 \text { National Table } \\
\text { Tennis "Amateur King" } \\
\text { Finals [19] }\end{array}$ & $\begin{array}{l}\text { It is necessary to give full play to the role of table } \\
\text { tennis in promoting the physical health of the whole } \\
\text { people, respond to the COVID-19 epidemic with } \\
\text { active table tennis, combine amateur table tennis with } \\
\text { domestic and international competitions, provide } \\
\text { professional guidance and development platforms for } \\
\text { more table tennis players. }\end{array}$ \\
\hline
\end{tabular}

\subsubsection{Technological progress}

The progress of Internet technology is gradually subverting our way of life. According to the "Statistical Report on Internet Development in China", as of June 2020, the Internet penetration rate approaches 65\% [20]. It can be seen

ISSN: 0010-8189 
that China's network market has a large development scale, which has gradually integrated into all aspects of national development. Therefore, for the development of Chinese sports industry, it is also necessary to use advanced Internet technology to further promote the development of Chinese sports industry through the support and development of Internet technology. In earlier time, if we wanted to watch major table tennis competitions (such as the Olympics, World Cup, World Championships), we had to depend on live TV and official websites. The time was fixed and rigid. Now, with the advancement of Internet $4 \mathrm{G}$ and $5 \mathrm{G}$ technologies, we can watch live broadcasts and replay game videos via mobile phones anywhere, anytime, thus facing less restriction by time and space. For example, many table tennis official accounts in WeChat have played an important role in promoting table tennis-related information and cultural dissemination. For example, before the competition, the official account will often provide key information in detail such as introductions of competitions, participants, game time. It also explains the basic movements of table tennis in other sections with special explanation videos for attacking, driving, and chipping. This provides a more convenient and faster channel and platform for table tennis enthusiasts or those who want to learn about table tennis, which has greatly promoted the popularization and dissemination of table tennis culture.

\subsection{Threat}

Affected by the epidemic, the income growth of residents across the country is limited, some even lose job and go bankruptcy, having no source of income. Faced by such a severe situation, people will inevitably make trade-offs and reduce some unnecessary living costs. In the first quarter under the epidemic impact, the job market's prosperity declined significantly. Where, GDP fell by $6.8 \%$, and the urban unemployment rate rose sharply from $5.3 \%$ in January to $6.2 \%$ in February. The CIER index also dropped sharply from 2.18 in the fourth quarter of 2019 to 1.43. At the same time, China's per capita consumption expenditure on education, culture and entertainment in the first quarter of 2020 was 350 yuan, accounting for only $63.9 \%$ of the previous one, which is the sector with the biggest fall among all consumption compositions [21].

\section{Suggestions forOptimizing the Development of Table Tennis Events in ChinaBased on the SWOT-PEST Model}

3.1 SO Strategy (Strength + Opportunity)-Inherit the national table tennis culture and conform to the trend of the times

Table tennis, known as the "national sport", has a profound background and a broad mass base, which exerts an extraordinary influence on the development of table tennis in the new era. First of all, national table tennis culture needs to be passed on from generation to generation: to understand the development process of table tennis in China, and to learn its inherent national table tennis culture and spirit. Second, it is necessary to respond to the call of the national government's policies, catch the express train of technological development, and follow the trend of the times. The development of table tennis in the new era requires support from national policies and the help of technological development (short video, 5G technology, VR technology),so that publicity is more diversified. In this way, people who love table tennis can appreciate and participate in table tennis from more different angles and forms, and groups who have never been in contact with table tennis can be attracted to get in touch with and learn about the sport of table tennis.

3.2 ST Strategy (Strengths + Threats)-Give full play to the event's own strength, strengthen the body and guard against COVID-19

Under the epidemic impact, residents' work and income face severe challenge, and what follows will be the reduction of various unnecessary expenditures. However, as the epidemic has not receded, residents' health has become an important topic. Table tennis is an event that requires a small area compared to sportssuch as basketball, football, volleyball, and it can be performed indoors. We should give play to the advantage of the table tennis event itself. During the epidemic, we can purchase a table of suitable size at home for daily physical exercise. First of all,

ISSN: 0010-8189

(C) CONVERTER 2021

Www.converter-magazine.info 
the risk of infection due tooutdoor exercise will be reduced to zero, and the event exercisesthe body with fun, thus enhancing the feelings between family membersto a certain extent, and solving the physical exercise needs of a family without the need for going outside.

3.3 WO Strategy (Weakness+ Opportunity)-Innovate the content and form of propaganda, leverage scientific and technological means.

The reason why table tennis has not received particularly high attention in recent years is that, to a large extent, table tennis competitions are not highly watchable and the national table tennis teammonopolies gold medals. First of all, the publicity of the Chinese table tennis team should not be limited to their performance in international competitions. It is possible to record and publicize the training and daily life behind the athletes, raise the public's concern and interest from a different perspective, so that more people participate in table tennis. Secondly, with 5G, VR technology, etc., to a large extent, it is possible to present the ordinary TV 2D boring game rebroadcasting screens in more diversified forms in front of the audience, thus reducing the problem ofsingle viewing angle of the game due to location, environment, unclear screens.

\section{Conclusion}

In the new era, domestic development of table tennis sports is facing severe challenges such as the epidemic impact. Now, we propose the following suggestions for the future development of this event: Inherit the national table tennis culture and conform to the trend of the times; give full play to the event's own strength, strengthen the body and guard against COVID-19; innovate the content and form of propaganda, leverage scientific and technological means. With the advancement of science and technology in recent years, the optimization of the external environment will enable positive trend in development of table tennis sports, thuscontributing to the development of national sports and general health.

\section{Acknowledgements}

This work was supported by the FundamentalResearch Funds for the Central Universities (2020SKTY01).

\section{References}

[1] N. Dan, "SWOT analysis of the operation of Beijing Marathon," Journal of Physical Education, vol. 21, no. 06, pp. 19-23, 2014.

[2] N. Lei, M. X. Guo, Y. B. Gao, "PEST analysis of public sports service items for Chinese ice and snow sports," China School Physical Education (Higher Education), vol.5, no. 09, pp. 1-5, 2018.

[3] S. X. Li, H. G. Jing, "SWOT analysis and countermeasures for the development of traditional ethnic sports tourism industry in Foshan City," Journal of Guangzhou Sport University, vol.39, no.06, pp. 59-62, 2019.

[4] L. Luo, "SWOT-PEST analysis of the sustainable development of competitive sports in Shanghai, "Journal of Hubei Sports Science, vol. 35, no. 11, pp. 965-967, 2016.

[5] X. F. Wang, “The contemporary value of Mao Zedong's sports thought and spirit_—Talking from "Sports Research"," Journal of Nanjing Sport Institute (Social Science Edition), vol. 31, no. 06, pp. 19-22, 2017.

[6] H. Y. Xiao, J. S. Ni, "The role and enlightenment of sports cultural exchanges on the improvement of Sino-U.S. relations: Based on a historical survey on Sino-U.S. diplomatic relations over 40 years." Journal of Wuhan Institute of Physical Education, vol. 53, no. 10, pp. 12-18, 2019.

[7] T. Y. Chen, "Research on the value and scientific training of youth table tennis,"Youth Sport, no. 09, pp. 78-79, 2019.

[8] Y. Q. Peng, FuxinYun, X. Q. Weng, "The effect of 12-week table tennis exercise on the dynamic balance of the elderly,'Journal of Guangzhou Sport University, vol. 38, no. 05, pp. 103-105, 2018. 
[9] Y. C. Qiao, “A Research on How Body-building Retards the Ageing Process ( II) Body-buildings Regulating Effects on Nerve-Endoctrine-Immunity Network," Sport Science, vol. 23, no. 03, pp. 103-108, 2003.

[10] “Department of Sports Economics," National Sports Site Statistics Survey Data in 2019,2020.

[11] X. Wang, Q. C. Liang, L. Li, “Critical reflection on the frequent revisions of the ITTF rules," Journal of Wuhan Institute of Physical Education, vol. 54, no. 10, pp. 88-94, 2020.

[12] J. P. Xi, "Speech at a forum of expert representatives in the field of education, culture, health and sports,"People's Daily, 2020.

[13] Anonymous, "Li Keqiang presided over an executive meeting of the State Council," People's Daily, 2015.

[14] "Opinions of the general office of the state council on strengthening physical education in schools to promote students' all-round development in physical and mental health,” 2016.

[15] Anonymous, Puyang, Henan: Polish the city's vitality card, table tennis. China Sports News, 2019.

[16] Anonymous. Fun table tennis contributes to home fitness. China Sports News, 2020.

[17] "Announcement of the Chinese Table Tennis Association on the Establishment of the National Table Tennis Youth Training Team and Children's Training Team," Chinese Table Tennis Association, The official website of the Chinese Table Tennis Association, 2020.

[18] Anonymous. Sichuan staged table tennis competitions on the field. China Sports News, 2020.

[19] Chinese Table Tennis Association. Supplementary Notice on the 2020 National Table Tennis "Amateur King" Finals. Official website of Chinese Table Tennis Association, 2020.

[20] Cyberspace Administration. The 46th "Statistical Report on Internet Development in China", 2020.

[21] X. Q. Zeng, "Expert: It is necessary to further release and thoroughly interpret various data such as labor force surveys," 2020. 